Marquette University

e-Publications@Marquette

Philosophy Faculty Research and Publications

Philosophy, Department of

9-1-2013

\title{
Third Parties and the Social Scaffolding of Forgiveness
}

Margaret Urban Walker

Marquette University, margaret.walker@marquette.edu

Accepted version. Journal of Religious Ethics, Vol. 41, No. 3 (September 2013): 495-512. DOI. (C) 2013 Wiley-Blackwell. Used with permission. 


\title{
Third Parties and the Social Scaffolding of Forgiveness
}

\author{
Margaret Urban Walker \\ Department of Philosophy, Marquette University \\ Milwaukee, WI
}

It seems a widely accepted truth that only the one to whom a wrong has been done can forgive that wrong. This is sometimes called the victim's "right" or "prerogative" to forgive. The claim that only victims can forgive can be treated as a conceptual truth, true by the definition of what we call "forgiving." But what we mean by "forgiving" is in dispute at the heart of this question (and others). So I am inclined to think of this truth, if it is one, as a claim that results from understanding what forgiveness involves, and the real human conditions, costs, and effects of its being granted (or denied).

Several philosophers, however, have recently been drawn to defending the reality and importance of "third party forgiveness" (3PF), the scenario in which $A$ forgives the offender $B$ for something $B$ did to the victim $C$, where $A$ is not plausibly seen as a fellow victim, and where $A$ forgives $B$ on A's own behalf, not on behalf of $C$ or anyone else who might be a victim of the wrong. In this paper, I am going to look in particular at philosopher Glen Pettigrove's defense of 3PF (Pettigrove 2009). Pettigrove's is the clearest and most direct defense, and studying it helps to show that the issues are not conceptual ones of the "logic" or "grammar" of forgiving, but rather of

Journal of Religious Ethics, Vol. 41, No. 3 (September 2013): pg. 495-512. DOI. This article is (c) Wiley and permission has been granted for this version to appear in e-Publications@Marquette. Wiley does not grant permission for this article to be further copied/distributed or hosted elsewhere without the express permission from Wiley. 
understanding what goes on in forgiving, why it is necessary, and why it is hard. ${ }^{1}$ I will defend the victim's prerogative or unique standing to forgive, not only against Pettigrove, but in general against the claim that third parties can forgive, where third parties are those who have suffered no wrong. My argument, in bald form, is that wrongs that require forgiveness inflict severe and inescapable costs of distinctive kinds upon victims. It is profoundly unjust that victims should have to bear these costs, and impossible for wrongdoers (even where willing and repentant, and even where already punished or having made amends) to undo or erase them. In forgiving, victims must absorb some, and often most or all, of these costs. It is precisely this plight inherent in the situation of the victim (and the wrongdoer) that makes forgiveness so hard and so valuable, but it is precisely this plight that "third-parties" do not share.

At the same time, I recognize that those proposing third party forgiveness are trying to reveal something important about forgiveness in actual contexts where responding to serious wrongs has emotional, material, social, and moral stakes for those beyond the victims of wrongs and the wrongdoer. Even if it is solely the victims of wrongs who are entitled to and able to forgive those responsible for the wrongs, there are significant, even essential, roles played by third parties - where these are neither victims nor wrongdoers, and where these can include intimates, friends, and strangers - in making forgiveness possible, reasonable, or valuable. They can also make it difficult, punishing, or empty. That is why "third parties" matter to forgiveness. How they do so, I undertake to explain.

\section{Pettigrove on Third Party Forgiveness}

I begin with Pettigrove's clear and direct positive argument for 3PF. The argument is:

1. Moral wrongdoing provokes hostile reactive attitudes, including resentment and hatred of wrongdoers, and forgiving commonly involves overcoming these negative attitudes.

2. Wrongdoing tends to disrupt relationships, creating estrangement and distance among persons, and forgiving

Journal of Religious Ethics, Vol. 41, No. 3 (September 2013): pg. 495-512. DOI. This article is @ Wiley and permission has been granted for this version to appear in e-Publications@Marquette. Wiley does not grant permission for this article to be further copied/distributed or hosted elsewhere without the express permission from Wiley. 
commonly involves repairing relationships disrupted by wrongdoing.

3. Wrongdoing invites negative reflection on the character of wrongdoers and forgiving involves positive revaluation of the character of wrongdoers.

4. While overcoming negative reactive attitudes, repairing disrupted relations, and revaluing wrongdoers' characters are none of them individually necessary for forgiveness, they seem to be jointly sufficient to have forgiven.

5. Persons other than a victim of wrongdoing can engage in each of these activities, and sometimes engage in all of them, with respect to a person who has wronged another.

6 . Therefore, persons other than victims of a wrongdoing can forgive the one who has done that wrong.

Pettigrove's positive argument draws attention (as many accounts of forgiveness do not, but proponents of third party forgiveness invariably do) to the intricate social web in which wrongdoing reverberates around the victim(s) and the wrongdoer. He also rightly avoids the mistaken but prevalent view that resentment toward a particular wrong can only be experienced by a victim of wrong, although I offer a different account of this later (Pettigrove 2009, 587). However, even if one accepts the premises of Pettigrove's argument, the argument alone cannot close the case for 3PF. One can concede that those other than victims wrestle with negative reactive feelings, relationship rifts, and convictions of deficient or bad character, yet deny that what they do in overcoming these is forgiving, precisely because one believes, for other important reasons, that forgiveness is something only victims can do. So the argument results only in a stalemate.

Perhaps for this reason, Pettigrove also undertakes to rebut three representative lines of argument against 3PF. ${ }^{2}$ First, there is the argument that forgiveness is like cancelling a debt, and only the person who is owed the debt can cancel it. He finds unfortunate the "image of social life in which we are all moral bookkeepers" (Pettigrove 2009, 584). Were we to accept the analogy, however, the argument ignores the reality of third party debt cancellation, as in cases of bankruptcy and arbitration. Second, there is the argument that 
forgiveness is overcoming or forswearing resentment, and only the victim can experience the resentment that forgiveness must overcome. While it has become a common claim, following Peter Strawson, that resentment is nonmoral anger felt at wrongs to oneself, Pettigrove rightly rejects this view of resentment. ${ }^{3}$ He adapts Bishop Butler's view that resentment is a stronger, more persistent, and more partial (i.e. less objective) kind of indignation that, while characteristically felt at wrong to oneself, is also commonly experienced at wrongs to others about whom one cares or with whom one identifies. On this view, third parties can experience their own resentment at wrongs to others, so 3PF does not incoherently suggest that third parties overcome someone else's resentment, or that in overcoming their own resentment they forgive for or in place of the victim. Finally, there is the argument that only the victim can forgive, because only the victim can judge or decide that his or her relation with the wrongdoer is (or can be) restored. In response, Pettigrove notes that we as third parties sometimes find ourselves estranged from wrongdoers because of what they have done to others. Once estranged, we find ourselves with our own strained relationship to mend. Pettigrove does not deny that third parties might face different considerations than victims about whether to forgive. For example, a third party's continued anger and estrangement from the offender might serve as a valuable and needed supportive message to the victim that she or he is worthy of respect that the wrongdoer did not show, or it might serve as a warning to a wrongdoer who might still threaten the victim. These are differences in motivation or reason to forgive or not to forgive in particular cases, not differences between those who can forgive and those who cannot.

Pettigrove rests his defense of 3PF on "the functional and experiential similarity" between what victims and third parties do (together with the - philosophically inconclusive - availability of such everyday expressions as "I cannot forgive her for what she did to him!") (Pettigrove 2009, 594). He claims this makes it reasonable to see them as doing the same thing, albeit perhaps from distinctive positions that introduce some distinct normative considerations. Pettigrove believes other features also recommend his account. He says it is faithful to the "phenomenology" of our responses to wrongs done to others. It seems to me, however, that victims of wrongs and those who care about them may well be feel baffled, betrayed, or

Journal of Religious Ethics, Vol. 41, No. 3 (September 2013): pg. 495-512. DOI. This article is @ Wiley and permission has been granted for this version to appear in e-Publications@Marquette. Wiley does not grant permission for this article to be further copied/distributed or hosted elsewhere without the express permission from Wiley. 
insulted by the presumption of would-be third party forgivers; offenders who are "forgiven" by those they did not harm might be impatient or indignant, as well. ${ }^{4}$ That phenomenology, too, requires explanation. Pettigrove believes 3PF clarifies the ethical appropriateness of forgiveness and apologies, but this is true only if he is right about 3PF. Finally, and seemingly most important, he thinks 3PF acknowledges our interconnected lives. In the closing sentence of his paper, Pettigrove says, "...a person's forgiving and readiness to forgive depend not only on states internal to that agent but also on relations between that agent and significant others around her, a set that includes but is not exhausted by the wrongdoer" (Pettigrove $2009,599)$. With this, I very much agree, but I do not believe 3PF is the right way, descriptively or morally, to honor this insight. What I need, however, is a strong argument for what, exactly, the defender of 3PF gets wrong.

\section{Hieronymi's Limited Account of Forgiveness}

To start, I avail myself of Pamela Hieronymi's perceptive but limited account of forgiveness. Hieronymi offers an account of what forgiveness does that explains why forgiving becomes reasonable in those cases where the offender apologizes (Hieronymi 2001). ${ }^{5}$ The puzzle is that forgiveness is only needed if it remains true that the act in question was wrong; that the wrongdoer can be legitimately held to our expectations, and is responsible for his behavior; and that the victim herself did not deserve this treatment. If any of these judgments is given up, then we lack an offense, an offender, or a victim. Yet if the three judgments of wrong action, responsibility of the wrongdoer, and moral worth of the victim are warranted, Hieronymi says, "our first response is, and ought to be, anger and resentment" (Hieronymi 2001, 530). So, how can the apology give the victim a reason to relinquish resentment while leaving these three judgments, and the need for forgiveness, intact?

Hieronymi's explanation is the resentment that forgiving overcomes is a sort of "fight response" (Butler called it "a weapon"); more specifically, it is a protest of "a past action that persists as a present threat" (Hieronymi 2001, 546). Resentment responds not only to the judgments of wrong, responsibility, and victim worth, but to the

Journal of Religious Ethics, Vol. 41, No. 3 (September 2013): pg. 495-512. DOI. This article is @ Wiley and permission has been granted for this version to appear in e-Publications@Marquette. Wiley does not grant permission for this article to be further copied/distributed or hosted elsewhere without the express permission from Wiley. 
additional threatening claim implied by a wrong action: that the victim can be treated this way. The wrong action makes this claim, the claim constitutes a threat, and the threat "persists in social space" unless and until it is rebutted or undermined $(2001,550)$. One could deflate the threat by denying that what was done was wrong, or that the wrongdoer is responsible, or that the victim deserved better, but then there is nothing left to forgive. If the facts of wrong, responsibility, and the victim's worth stand, however, there is something to protest and resentment is the emotional expression of that protest. Resentment "fights the meaning of the past event, affirming its wrongness and the moral significance of the victim and the wrongdoer" $(2001,547)$. When the wrongdoer apologizes and repents, however, she retracts or undermines the threatening claim, so the protest that is resentment is no longer fitting.

It might seem here that Hieronymi's account opens the door to 3PF, since it seems that others' protest might also express itself emotionally as resentment, putting them in a position to forgive by overcoming or forswearing their own resentment. But there is more to her account. Solving the puzzle of how apology makes it reasonable to let go of resentment raises another puzzle in turn: if the apology retracts the implied claim and removes the threat, what is left for the victim to do in forgiving? Hieronymi suggests two remaining roles for the victim. First, because our identities and the meanings of our acts are "thoroughly social," not the sole property of the offender, the offender needs the retraction of the threat she has posed to be "ratified" by others, and in offering forgiveness, the victim "joins forces" with the wrongdoer decisively to change the meaning of the wrongful act $(2001,550)$. Second, Hieronymi reminds us that regardless of the wrongdoer's remorse, contrition, or repentance, serious wrongs leave damage of physical, emotional, material, or social kinds. While the wrongdoer's heartfelt retraction might dispel the threat implied by her treatment of the victim, she usually cannot repair all the damage, and in many grievous cases, she cannot repair any of the damage, her wrongful act has done to the victim. She can, so to speak, retract the threatening insult but not the injury. "With forgiveness," Hieronymi claims, "the offended agrees to bear in her own person the cost of the wrongdoing and to incorporate the injury

Journal of Religious Ethics, Vol. 41, No. 3 (September 2013): pg. 495-512. DOI. This article is @ Wiley and permission has been granted for this version to appear in e-Publications@Marquette. Wiley does not grant permission for this article to be further copied/distributed or hosted elsewhere without the express permission from Wiley. 
into her own life without further protest and without demand for retribution" (2001, 551).

Although Hieronymi has little to say on this second point, it is central to seeing what is wrong with the idea that third parties can forgive, whatever else they may and must do. The fact that her account is limited to cases of repentant and apologetic offenders actually sharpens the point. It drives home the fact that even when the wrongdoer does everything she can do to own up, apologize, atone, and make amends, any serious wrong pitches its victim, without any choice in the matter, into a situation fraught with distress and harm; where the harm is severe, the response may include rage, mistrust, despondency, terror, or grief. Hieronymi reminds us that "Forgiveness is not simply a revision in judgment or a change in view or a wiping clean or a washing away or a making new. Someone will bear the cost in his or her own person. The wrong is less 'let go of' or washed away than it is digested or absorbed" (2001, 551n39).

Here lies the core of truth in the "debt model" that Pettigrove derogates as an image of social life "in which we are all moral bookkeepers who are busy keeping a tally of what we owe and what we are owed" (Pettigrove 2009, 584). Grave wrongs done to us can deprive us of important goods (such as trust, self-confidence, ease, security, or people and things we love) and they saddle us with predicaments that range from difficult and unsettling to disastrous and life-changing. Someone else has caused this to happen to me; I had no choice, but it is I who must struggle. This is an experience at the root of a simple sense of justice: I should not have to "pay," and someone else should.

This intuitive and (so far as I know) universal human sense of justice can propel either retributive or reparative demands, but either sort of demand insists that the wrongdoer not leave me with the costs she has caused me to bear. It is why forgiveness of terrible wrongs can be moving, admirable, or even astonishing, and why the ability to give it is often seen as virtuous, since it may require generosity, compassion, courage, equanimity, or resilience. It is why forgiveness is often spoken of as a gift, even when wrongdoers apologize and offer amends. It is why it seems trivializing or ridiculous to speak of "forgiving" someone for negligible wrongs or for wrongs that do little

Journal of Religious Ethics, Vol. 41, No. 3 (September 2013): pg. 495-512. DOI. This article is @ Wiley and permission has been granted for this version to appear in e-Publications@Marquette. Wiley does not grant permission for this article to be further copied/distributed or hosted elsewhere without the express permission from Wiley. 
or no harm. In trivial or slight cases, apology to the offended parties may still be appropriate and necessary, as a display of acknowledgment that rules have been broken or as a show of respect where some consideration has been lacking. But for one mildly offended to represent himself as forgiving the offender where there is no harm or only slight cost is overdramatizing or excessive - that would indeed be an unfortunate form of scorekeeping. ${ }^{6}$

The reminder of "cost" brings out the full impact of serious wrongs among human beings, where damages of wrongdoing are never just washed away, even when there is retribution or reparation. This is why 3PF hangs somewhere between incoherence and insult. Only a victim is left with the damage; that is what it is to be a victim, and that is at the core of the problem to which forgiving is a response. The fact that significant damage can propagate through our social and emotional bonds (to the families of murder victims or to the members of the group targeted in a hate crime) is what makes for talk of direct and indirect, or primary and secondary, victims. But to represent oneself as forgiving just because one is aware of a wrong and enters into the fellow feeling of resentment, is myopic, or even self-indulgent or presumptuous. It is as if one treated one's moral responses of indignation or outrage at wrongs to others as a kind of harm one suffers, or worse, as a kind of harm in some way akin to the damage with which victims of serious wrongs struggle.

Hieronymi's point about absorbing damage tells against 3PF, although her discussion of the role of resentment in forgiveness initially looked as if it might have permitted it. If resentment is the emotional expression of protest against what the wrong implies, and if Pettigrove is right, as I also think, that resentment at wrongs is not confined to victims, the account might seem to favor 3PF in the following way. Wrongs create resentment, not only in victims; the function of resentment in the economy of shared moral life is to protest the demeaning message the wrong implies; all those who feel resentment effectively join in the fight to protest that message, pending its retraction, putting all resentful parties in the position to forgive; so, insofar as forgiveness involves relinquishing resentment for the right kind of reason, the wrongdoer's repentance provides all resentful parties with the right reason to forgive, since the wrongdoer

Journal of Religious Ethics, Vol. 41, No. 3 (September 2013): pg. 495-512. DOI. This article is @ Wiley and permission has been granted for this version to appear in e-Publications@Marquette. Wiley does not grant permission for this article to be further copied/distributed or hosted elsewhere without the express permission from Wiley. 
is retracting the demeaning message and asking others for the ratification of that retraction in social space.

The fact that the victim alone must accept and absorb many kinds of damage in forgiving, however, decisively blocks that implication. But Hieronymi gave two reasons why the victim of wrong has something important to do in forgiving, even when resentment is no longer fitting. Hieronymi says the wrongdoer needs the victim to "ratify" that the threat implied by the wrongdoing has indeed been retracted. But this invites the question: why, on Hieronymi's account, is forgiveness by the victim so weighty or decisive in "ratifying" the offender's retraction of the demeaning message, and thus in making it reasonable to give up resenting what the offender has done? If resentment is correctly explained as a protest of the threatening message against the victim's standing that is the meaning of the wrongdoer's act, and if the meaning of what we do is "thoroughly social," and the retraction of the message requires "ratification" by others, why is the victim's forgiveness either necessary or sufficient for the retraction to be ratified? Unlike the absorption of costs, the retraction of implied moral insult does not seem to belong exclusively or specially to the victim. Indeed, if the wrongdoing can actually threaten the victim's standing, can the victim alone neutralize this threat, even if the wrongdoer repents? Conversely, cannot others see to it that the demeaning message is "contradicted" by their show of respect for the victim and their repudiation of the wrongdoer's act? Cannot others, standing together and with the victim, do this to an extent that the victim alone could never do? Something in her explanation of the nature and role of resentment is not quite right.

\section{Getting Resentment Right: A Revised Account}

Hieronymi's point that forgiveness requires the victim to absorb damages without or beyond retribution or amends is independent of her particular account of resentment. The victim's burdens of unrepaired or irreparable damage are something any account of forgiveness must recognize as the part of the setting for forgiveness and a good part of what makes forgiving arduous. The nature of resentment, and its role in the economy of moral relations and responses, however, has some special importance in appreciating how

Journal of Religious Ethics, Vol. 41, No. 3 (September 2013): pg. 495-512. DOI. This article is @ Wiley and permission has been granted for this version to appear in e-Publications@Marquette. Wiley does not grant permission for this article to be further copied/distributed or hosted elsewhere without the express permission from Wiley. 
third parties matter. In this section, I hope to sort out some connections among wrongs, resentment, offenders, victims, and third parties. In the following section, I will return to the emotional situation of the wronged party, and to the consequential roles that third parties can play with respect to both the victim and wrongdoer. I aim to leave forgiveness to victims, but also to honor our interconnected moral and social lives.

My own account of resentment, developed in detail elsewhere, is that resentment is a reactive attitude that arises in response to the conduct of other moral agents that is perceived to violate norms of many types (Walker 2006b, 110-50). Important for my view is the ubiquity of resentment; this rebuking anger extends widely throughout social life. Resentment is certainly a common response to perceived wrongs to oneself, but it extends to wrongs done to others. Importantly, it extends to wrongs both to others about whom we care and to others whom we do not know. We can resent contemptuous treatment we witness visited on a stranger, and we can resent abuses of power or violence toward innocents we learn about in the news. But resentment ranges wider still. People frequently resent victimless transgressions of social norms. They resent what they believe are unacceptable forms of attire and hairstyles; what they see as inappropriate behavior in public places. They resent others who talk too loud and too long; bring "foreign" customs and languages into their familiar spaces; act too friendly or intimate in conventionally impersonal exchanges; or act outside or above what is assumed to be their "place." The vast field of resentments at apparently victimless offenses to presumed social order has a unifying explanation.

The unifying explanation is that resentment is the reactive emotion in human beings that aims at policing compliance with norms generally, and not only moral norms. It aims to keep people inside bounds and at their stations, where the boundaries and places are defined by norms that those who resent believe are authoritative for shared life. Pettigrove, who uses third party resentment along with third party reconciliation and revaluation of wrongdoers, to support $3 \mathrm{PF}$, correctly insists that resentment rises to wrongs done to others, and not only to wrongs done to ourselves. He sees that we resent wrongs done to others with whom we are personally connected, linking this to Butler's description of resentment as an especially partial (not

Journal of Religious Ethics, Vol. 41, No. 3 (September 2013): pg. 495-512. DOI. This article is @ Wiley and permission has been granted for this version to appear in e-Publications@Marquette. Wiley does not grant permission for this article to be further copied/distributed or hosted elsewhere without the express permission from Wiley. 
impersonal or disinterested) kind of anger. But one of his own examples of other-regarding resentment does not fit his view of resentment as essentially "partial." In his example, a "compassionate observer" - a U.S. citizen who resents mistreatment of workers in the maquiladoras on the border about whom he reads in the newspaper is supposed to be moved to resentment by a vivid portrayal that incites his own sympathetic character (Pettigrove 2009, 587). A case like this, however, does not fit the mold of partiality. Those moved to resentment by reports of distant wrongs need not be especially sympathetic, for they need only care about the moral principle at stake; and the account that mobilizes their censure may be a factual report rather than a dramatic narrative or moving depiction.

There is a better explanation of the whole range of resentments, and it is this: resentment is anger that responds rebukingly to those believed to violate shared norms. Resentment, in "protesting" the violation, defends both the authority of those norms and the resenter's own standing as a competent judge of the normative order. The sense in which one takes "personally" what one resents is compatible with this understanding, but not in the sense that one must see a normative transgression as a wrong to oneself, or even to those with whom one identifies or about whom one cares. On the whole, human beings take the normative structures on which they depend seriously, where these structures include basic moral precepts, rules of etiquette or manners, norms of appropriate attire, modes of address, or conventions about giving and receiving gifts. If we cease to take norms seriously, the authority of norms erodes. This makes resentment - a norm-enforcing response - a central reactive emotion for intensively norm-instituting social beings. My view comports with Butler's enduring point that resentment is a "fellow feeling" that rises in defense of others as well as ourselves, but it manifestly goes beyond injury or injustice. Where there is wrong or injustice, even when it is done to ourselves, the resentment rises to the defense of those norms that define the action as wrong, the actor as responsible, and the victim as worthy of consideration. The norms on which we rely, moral and nonmoral, not only protect us, but coordinate a variety of expectations in social life. ${ }^{7}$

Journal of Religious Ethics, Vol. 41, No. 3 (September 2013): pg. 495-512. DOI. This article is @ Wiley and permission has been granted for this version to appear in e-Publications@Marquette. Wiley does not grant permission for this article to be further copied/distributed or hosted elsewhere without the express permission from Wiley. 
Hieronymi is thus right to see resentment as serving to protest a threat. Resentment is a kind of anger, and since in its overt expression it is pointed anger, accusing and rebuking an offending party, resentment is itself a spontaneous counterthreat. ${ }^{8}$ When the full range of evident resentments are considered, it appears that resentment is a natural and indispensable response that aims at policing shared life by rebuking violations of norms across a great variety of moral and social contexts. Resentment always invokes some presumed norm and at the same time asserts the resenter's standing as a competent judge within the community whose norms these are. The "partiality" in question in resentment is not essentially partiality to self and others, but consists in our caring about our security in a community with rules we can rely on, and our confidence in asserting the rules of a community we consider our own. Resentment presumes we are bound together and reinforces our normative ties.

The rules or norms resentment enforces are a common possession, or at least they are assumed to be shared by one who resents a violation. I believe my explanation of resentment is faithful to the facts, but in the present argument it has another virtue: it tells us why those not wronged, or not even connected to those wronged, often feel a stake in the enforcement of norms. Resentment from others toward a wrongdoer does defend a victim of wrong, but it does more. Resentment or indignation - like Butler and Adam Smith, I do not distinguish these - serves the vital function of affirming the worth of the victim, while also reasserting the authority of the norm and the responsibility of the offender. When wrong is done to someone, then, the failure of others to be moved to the censure expressed by resentment is an abandonment of either the norm, or the responsibility of the offender, or the victim. All of these are at stake: others' resentment stands with the victim, upon the norm, and against the offender (pending excuse or justification). Failure to so stand signals that one or more of these are something for which others are not prepared to stand up. The net effect in the economy of a life organized - or better, scaffolded - by shared norms, is that no individual can uphold the structure alone, yet any individual is exposed to actual or potential harm if the structure (or some structure) is not maintained by the actions and responses of enough others. Whether the rest of us take up our proper roles does affect, although it can 
never determine and should not try to supplant, what victims find themselves able or willing to do in the way of forgiveness.

\section{Costs to Victims and Third Party Roles}

Third parties have nothing to forgive, but have key roles in affirming norms, sanctioning offenders, and vindicating victims. Victims alone can forgive, but they can typically do little all by themselves to affirm shared norms, authoritatively sanction offenders, and to vindicate themselves in, as Hieronymi puts it, the "social space" in which the messages of right and wrong, responsibility, and moral worth circulate. What third parties can do in the wake of wrongdoing is distinct from what victims can do. What third parties can do has the power to thwart or support what victims might do, including deciding to forgive, absorbing the costs of wrongs without further demand or repayment. We all sustain together the social scaffolding of norms and accountability in which resentment plays a central role as, in Butler's words, "a weapon, put into our hands by nature, against injury, injustice, and cruelty" of which we ourselves need not be a victim (Butler 1970 [1726], 76). The scope of resentment well exceeds moral boundaries, but its enforcement of moral boundaries is its most important job.

What others do in affirming moral boundaries, assigning responsibility, and standing with victims affects the terms on which victims choose to forgive or not to forgive. They can make it easier or more difficult, safer or more risky, or more a release than a burden for the victim. Victims may indeed have their own reasons for this choice in their moral convictions, their faith, or their personal history with the wrongdoer. But it often matters whether the victim is validated and vindicated by others, whether the victim receives confirmation from others that their own sense of grievance is justified, and whether the victim finds that others are willing to impose rebukes and demands on the offender. Being validated and vindicated by others can reasonably affect the victim's decision whether to relinquish further demands on the offender. A victim whose experience is denied or slighted, or who finds the offender enjoys protection that amounts to impunity, or who realizes that he or she (the victim) is not the kind of person the

Journal of Religious Ethics, Vol. 41, No. 3 (September 2013): pg. 495-512. DOI. This article is @ Wiley and permission has been granted for this version to appear in e-Publications@Marquette. Wiley does not grant permission for this article to be further copied/distributed or hosted elsewhere without the express permission from Wiley. 
community will defend or protect, might still forgive, but he or she has distinctive reasons to take care in doing so.

When the victim is not supported by others, the victim must be concerned, for example, about whether forgiving would seem like condoning or caving in, inviting the contempt or further abuse of the wrongdoer. Unsupported by others, the victim may need to lay claim to his worth emphatically "in social space" as a matter of principle, as a call for others' support. When others do not respond to that call, the victim can be locked into the need for protest. The victim cannot afford to forgive. Conversely, unequivocal communal validation and vindication (when others appropriately rebuke a wrongdoer, or apply other sanctions) can free the victim to be more generous or hopeful, allowing the victim to feel free to forgive. Third parties can also contribute to the victim's and the offender's understanding of the wrong and its consequences. A victim might need time, but also help, in seeing what she has suffered in perspective and context; to see the wrongdoer clearly; to shore up her sense of self-respect and justified anger; to refuse to condone a wrong; or to forgive in the face of social disapproval. A wrongdoer might need others to combat her own denial, evasion, or excuses; to explain what the victim is going through; or to understand whether there are amends that could be made and whether it is too soon or too late to attempt them. Third parties can, of course, make prospects of forgiveness worse, but they can also make them better. ${ }^{9}$

As defenders of 3PF like to emphasize, third parties are in a position to make their own judgments about wrongs, the responsibility of wrongdoers, and their own responsibilities to victims. They have "choices of moral significance" to make about wrongs done to others (Radzik 2010, 82). They face choices to rebuke or avoid wrongdoers, or to support the wrongdoer's reacceptance or rehabilitation, whatever the victim does. I have already suggested that their choices may well have consequences for what the victim does, and that is part of the moral complexity of their position. Defenders of 3PF seem especially concerned with grudging victims who refuse to forgive repentant and deserving wrongdoers, and with stranded wrongdoers who can no longer pursue forgiveness from a victim who is dead. Here there are important tasks for third parties in responding to remorseful offenders

Journal of Religious Ethics, Vol. 41, No. 3 (September 2013): pg. 495-512. DOI. This article is @ Wiley and permission has been granted for this version to appear in e-Publications@Marquette. Wiley does not grant permission for this article to be further copied/distributed or hosted elsewhere without the express permission from Wiley. 
who struggle without forgiveness: to witness repentance; to encourage and affirm improvement; to advise or console; or to help reign in guilt or shame that is excessive, self-defeating, or self-indulgent. None of these is, or requires, 3PF.

On the side of a morally aware and remorseful offender, there is an echo of the victim's costs: if we do not succumb to self-deception, we all have to live with the wrongs we have done, how we have hurt others, and what it says about who we are. Even if we are now better, wiser, or changed people, we are still the person who did what we did and who was capable of doing it. Keeping hold of this inescapable fact, we can hope, is a resource for making better choices in the future, and for clearer understanding, if not greater compassion, toward others who do wrong. But however "forgiving" (as we do say) is the stance third parties take toward someone who has wronged another, it is not what the victim of wrong decides to do in forgiving, for third parties do not have the victim's costs to absorb.

There are hard and complex cases involving intercommunal or intergroup conflict, or the situations of victims who have been grossly mistreated based on their membership in a group that is targeted for abuse. In cases of extended intergroup conflict, there are many wrongs done to individuals by individuals, but cycles of retaliation can render the categories of victim and wrongdoer unclear. Decisions by individuals to forgive or not to forgive in some cases involving groups may carry, or may seem to carry, implications beyond the individuals involved. It might be true that wrongs one has individually suffered are so bound to one's identification as a member of an ethnic, racial, religious, or political community, that one cannot avoid having one's own decision to forgive or not to forgive appear to "represent" others. This may be a moral obstacle to forgiveness in some cases, as a victim might not feel it is simply and separately her own to give; but it might add larger meaning to the choice to forgive or not to forgive. At the same time, there are temptations in these cases for groups or communities to burden the individual victim of wrong - the woman raped in group vengeance or the father of the victim of a political murder - with the community's hatred or with its hope for peace or reconciliation. The "victim's prerogative" can be an important principle here for all concerned. It is also true that the understanding of "the

Journal of Religious Ethics, Vol. 41, No. 3 (September 2013): pg. 495-512. DOI. This article is @ Wiley and permission has been granted for this version to appear in e-Publications@Marquette. Wiley does not grant permission for this article to be further copied/distributed or hosted elsewhere without the express permission from Wiley. 
victim" - the one wronged and seriously harmed - will almost certainly vary with different cultural assumptions. If some of us find it natural to see members of the immediate family of a murder victim as fellow victims, the social or kin understandings of others might extend that category differently or more widely. This is all only to say, however, that who the victim is, and what it means for victims to forgive, is not always obvious. It is not to say that those other than victims are in a position to forgive.

Having seen (all too briefly and schematically) what it is up to third parties to decide and to do, I want to return to the victim's situation. We still need to broaden the picture of the emotional costs of wrongdoing to victims. In particular, I want to dislodge the grip of the wrong/resentment/payback-or-forgiveness motif that has so dominated philosophical thinking about forgiveness and other responses to wrongs. The idea that righteous anger is the characteristic and natural response, and perhaps the rational, virtuous, or morally sound response, to being the victim of wrong has exerted a powerful hold on Western philosophical thinking about forgiveness. Aristotle's discussion of the virtue of good temper has it as a mean between irascibility and the other extreme without a name, in which the one wronged is a "fool" who is "thought unlikely to defend himself; and to endure being insulted and put up with insult to one's friends is slavish." 10

The idea that wrongs prompt (and should prompt) reproving anger continues to dominate most discussions of forgiveness, and the definition of "overcoming resentment" continues often to be treated as the default definition of forgiving. ${ }^{11}$ This is arguably one way that accounts of forgiveness are gender-inflected, if only because the "right" response is one that is culturally the "manly" one. ${ }^{12}$ This is also a way that many accounts of forgiveness are incomplete or distorting for men and women alike, for serious wrongs take their emotional toll in many ways. Pettigrove acknowledges this, but his extended list of emotional reactions involves "anger, hatred, loathing, contempt, and scorn," that is, all combative, hostile emotions (Pettigrove 2009, 590). Hieronymi, on the other hand, recognizes her account is limited by not addressing cases in which forgiveness involves "disappointment, sadness, or frustration" (Hieronymi 2001, 553). My point is entirely

Journal of Religious Ethics, Vol. 41, No. 3 (September 2013): pg. 495-512. DOI. This article is @ Wiley and permission has been granted for this version to appear in e-Publications@Marquette. Wiley does not grant permission for this article to be further copied/distributed or hosted elsewhere without the express permission from Wiley. 
obvious once made: victims' responses to serious wrongs (not to mention terrible forms of mistreatment and violence) include, even frequently, disappointment, sadness, and heartbreak; helplessness, hopelessness, grief, and despair; shock, fear, rage, hatred, terror, and anguish; disgust and contempt; and guilt, humiliation, and shame. One compendium of crime victim statements includes these feelings, as well as "shattering, howling pain" and "visceral, animal anguish" (Zehr 2001, 26 and 48). ${ }^{13}$

To understand what is at stake in forgiving serious or terrible injuries, one needs to understand especially the roles of grief, despair, fear, mistrust, humiliation, and shame. The fact that a wrongdoer has retracted the insult to the victim implied by the wrong, or that third parties stand up decisively for the victim, might indeed answer the victim's protest of resentment in constructive ways. But what of grief at dealing with lost years and opportunities (in wrongful imprisonment, or in a marriage that turns out to have been based on deceit); or terror at a world turned malignant by torture or rape; or despair at the murder or disappearance of a child? There are also profound emotional experiences that do not fit neatly into packaged categories, such as the experience of being "haunted" by those lost to violence, or feeling "already dead" after the genocide or the concentration camp. ${ }^{14}$ Nor are such experiences confined to the most extreme cases; everyday betrayals, criminal victimization, and lives torn apart by the consequences of others' negligence can leave staggering emotional costs, alongside physical, material, and social ones. These emotional "costs" can warp or rend the victim's everyday existence, yet they are ones that the offender can barely touch, and for which others can only provide consolation.

Humiliation and shame deserve special attention. While the link between retaliation and anger seems to go without saying, humiliation and shame are powerful drivers of a need "get even." The anger or rage behind cycles of retaliatory violence, for example, may be rooted in shame, and by the need to prove to oneself as well as to others that one is not the lowly, miserable, contemptible object of another's will. ${ }^{15}$ Victims of personal betrayal can be ashamed at being of negligible concern to one whom they loved, and ashamed before others for being used or duped. Victims of criminal and political wrongs report shame

Journal of Religious Ethics, Vol. 41, No. 3 (September 2013): pg. 495-512. DOI. This article is @ Wiley and permission has been granted for this version to appear in e-Publications@Marquette. Wiley does not grant permission for this article to be further copied/distributed or hosted elsewhere without the express permission from Wiley. 
at being singled out for mistreatment by a stranger; at being helpless; at being reduced to the appearance of something less than human or to the behavior of an animal; and self-blame at surviving when others did not, or when they feel they did not do enough. This is all to drive home the point that mastering, containing, or absorbing the "costs" of grave or terrible wrongs, even just in the emotional sphere, is an arduous achievement that ordinary people nonetheless often do. That forgiveness of grave wrongs typically requires this feat draws a bright line between victims and all others even in the milder cases.

\section{Conclusion}

I have labored here over the idea of 3PF, which is not, after all, a majority view. Understanding what is wrong with it, though, is worth the effort. It is too easy to dismiss the claim that there is third party forgiveness as a contradiction or incoherence. What we really need is to understand what goes on in forgiveness, how it involves an unstable mix of action and passion, and why it is hard. Only then can we see why it is to the credit of the victim of wrong to find his or her way to lay down just demands and navigate powerful feelings, even as the victim's ability to do this can be deeply affected by the decisions and responses of others.

I prefer to describe forgiveness not as "overcoming resentment" but as the victim's making a practical commitment (either deliberate decision or by stages) to release the wrongdoer from further grievance, reproach, and direct demands to which the victim may yet be entitled (Walker 2006b, 151-190). In any case of serious wrong, this commitment will require the victim to refrain from trying to place remaining costs and damages on the offender to "pay" or relieve, and accepting the task of absorbing those costs. This characterization can capture a wide variety of cases which might or might not involve overcoming resentment or other negative feelings; restoring relationship with the offender; reevaluating or reframing the offender; or placing the wrong firmly in the past. Each of these is central to some cases; none of these is essential to all. They are all things that forgiveness might entail, and they are things that might be seen as tasks for others as well, but the victim's assumption of costs is something that no one else can do. ${ }^{16}$

Journal of Religious Ethics, Vol. 41, No. 3 (September 2013): pg. 495-512. DOI. This article is @ Wiley and permission has been granted for this version to appear in e-Publications@Marquette. Wiley does not grant permission for this article to be further copied/distributed or hosted elsewhere without the express permission from Wiley. 
NOT THE PUBLISHED VERSION; this is the author's final, peer-reviewed manuscript. The published version may be accessed by following the link in the citation at the bottom of the page.

\section{References}

Appiah, Anthony. 2010 The Honor Code: How Moral Revolutions Happen. New York: W. W. Norton \& Company, Inc.

Aristotle. 1980 Nicomachean Ethics. Translated by Sir David Ross. Oxford: Oxford University Press.

Butler, Joseph. 1970 "Upon Resentment."In Butler's Fifteen Sermons Preached at the Rolls Chapel and A Dissertation on the Nature of Virtue [1726], edited by T. A. Roberts, 72- 79. London: Society for Promoting Christian Knowledge.

Clark, Phil. 2010 The Gacaca Courts, Post-Genocide Justice and Reconciliation in Rwanda. Cambridge: Cambridge University Press.

Govier, Trudy, and Wilhelm Verwoerd. 2002 "Forgiveness: The Victim's Prerogative." The South African Journal of Philosophy 21: 97-111.

Griswold, Charles. 2007 Forgiveness: A Philosophical Exploration. New York: Cambridge University Press.

Hieronymi, Pamela. 2001 "Articulating an Uncompromising Forgiveness." Philosophy and Phenomenological Research LXII: 529-55.

Halpern, Jodi and Harvey M. Weinstein. 2004 "Empathy and Rehumanization After Mass Violence." In My Neighbor, My Enemy: Justice and Community in the Aftermath of Mass Atrocity, edited by Eric Stover and Harvey M. Weinstein, 303-22. New York: Cambridge University Press.

Hamber, Brandon. 2009 Transforming Societies after Political Violence: Truth, Reconciliation, and Mental Health. Dordrecht: Springer.

Hatzfeld, Jean. 2005 Into the Quick of Life: The Rwandan Genocide Survivors Speak. Translated by Gerry Feehily. London: Serpent's Tail.

Langer, Lawrence L. 1991 Holocaust Testimonies: The Ruins of Memory. Yale University Press.

Maclachlan, Alice. n.d. "In Defense of Third Party Forgiveness." Unpublished $\mathrm{ms}$.

Murphy, Jeffrie G., and Jean Hampton. 1988 Forgiveness and Mercy. New York: Cambridge University Press.

Norlock, Kathryn. 2009 Forgiveness from a Feminist Perspective. Lanham, Md.: Lexington Books. 2009 "The Standing to Forgive." The Monist 92: 583-603.

Radzik, Linda. 2010 "Moral Bystanders and the Virtue of Forgiveness." In Forgiveness in Perspective, edited by Christopher R. Allers and Marieke Smit, 69-87. New York: Rodopi.

Scheff, Thomas J. 1994 Bloody Revenge: Emotions, Nationalism and War. Lincoln, Nebraska: iUniverse.com, Inc.

Strawson, Peter F. 1968 "Freedom and Resentment." In Studies in the Philosophy of Thought and Action, edited by Peter F. Strawson, 71-96. New York: Oxford University Press.

Journal of Religious Ethics, Vol. 41, No. 3 (September 2013): pg. 495-512. DOI. This article is @ Wiley and permission has been granted for this version to appear in e-Publications@Marquette. Wiley does not grant permission for this article to be further copied/distributed or hosted elsewhere without the express permission from Wiley. 
NOT THE PUBLISHED VERSION; this is the author's final, peer-reviewed manuscript. The published version may be

accessed by following the link in the citation at the bottom of the page.

Walker, Margaret Urban. 2006a "The Cycle of Violence." Journal of Human Rights 5: 81-105.

2006b Moral Repair: Reconstructing Moral Relations after Wrongdoing. New York: Cambridge University Press.

Zehr, Howard. 2001 Transcending: Reflections of Crime Victims. Intercourse, Pa.: Good Books, 2001.

\section{Notes}

${ }^{1}$ Radzik 2010 offers an argument similar to Pettigrove's, based on supposed similarities between the experiences and situations of victims of wrongs and others who are not victims. Maclachlan n. d. offers a more complex account, which requires a special situation of sympathy and caring identification of the third party. Norlock 2009 also supports third party forgiveness, but Norlock stretches the understanding of victim forgiveness in some otherwise controversial ways. Griswold 2007 says he allows "third party forgiveness," but he means by it forgiving in place of someone else who is indisputably a victim, rather than forgiving a wrong done to another on one's own part. My discussion deals entirely with human interpersonal forgiveness of wrongs people do to each other. I do not take up forgiveness by God, although I doubt that it would be seen in those traditions to which it is central as a case of third party forgiveness. Nor do I discuss self-forgiveness here, but I accept the implication that if my argument against 3PF cuts against self-forgiveness as well, or allows self-forgiveness to be "forgiveness" only by analogy or metaphor, I accept that implication.

2 The three arguments Pettigrove attempts to rebut closely track those offered by Govier and Verwoerd 2002.

${ }^{3}$ Strawson 1968, 74-77, contrasts resentment as a "non-detached" reactive attitude that "the offended person might naturally or normally be expected to feel" (77), with indignation as an analogous but "sympathetic or vicarious or impersonal or disinterested or generalized" feeling toward wrongs done to others (84). This has become a default position in philosophical discussions. A common reference for this widespread contemporary view is Murphy and Hampton 1988. I present an extensive critique of the claim that resentment is necessarily self-referring in Walker 2006b. Pettigrove returns (as I do) to the classic discussion of Bishop Joseph Butler 1970 [1726], who understands resentment as a "fellow feeling," not confined to injury to oneself. Butler does, however, confines proper resentment to injury and injustice, as I do not.

Journal of Religious Ethics, Vol. 41, No. 3 (September 2013): pg. 495-512. DOI. This article is @ Wiley and permission has been granted for this version to appear in e-Publications@Marquette. Wiley does not grant permission for this article to be further copied/distributed or hosted elsewhere without the express permission from Wiley. 
NOT THE PUBLISHED VERSION; this is the author's final, peer-reviewed manuscript. The published version may be accessed by following the link in the citation at the bottom of the page.

${ }^{4}$ Radzik 2010 acknowledges that third parties who expressly announce their forgiveness to wrongdoers are apt to receive a hostile response to what might seem to them a "passive-aggressive punishment more than gift of compassion;" so she suggests that third party forgivers might well "refrain from explicitly declaring the forgiveness they justifiably and virtuously feel" (81). This is a curious result, as is Radzik's claim that third parties may forgive although they have no claims to apology or reparations on their own behalf (78).

${ }^{5}$ Hieronymi does not take up unilateral forgiveness, where apology or repentance is not on offer; nor does she take up self-forgiveness or forgiveness in the grip of emotions such as "disappointment, sadness, or frustration rather than resentment" (553).

${ }^{6}$ Social worlds have existed in which honor codes among an elite make insult easy to do and deadly to pay for. In some places, they still exist. On the erosion of such worlds of potentially deadly scorekeeping, see Appiah 2010.

7 See Walker 2006b, 133 and 146-47, on how being able to feel oneself a competent normative judge can be at stake in wielding resentment, and how resentment at changes in the shared norms of a community can give rise to resentments at feeling alienated, no longer a competent "one of us."

${ }^{8}$ See Walker 2006b, 133-36, on the social reality that not everyone in every circumstance is able to publicly threaten just anyone else. Butler was wrong to think that everyone equally can take up these "arms."

${ }^{9}$ For a sobering account of intense communal pressure not to reconcile or forgive across groups, see Halpern and Weinstein 2004. See also Clark 2010, 308-341, who claims that church leaders and Christian belief have been effective in encouraging reconciliation in postgenocide Rwanda.

${ }^{10}$ Aristotle 1980, 97.

${ }^{11}$ See Walker 2006b, 154-158, for reasons that this description will not do.

12 Norlock 2009 explores the ways forgiveness, in concept and practice, is gendered.

${ }^{13}$ See also Walker 2006a on the consequences of oversimplifying victim's reactions.

Journal of Religious Ethics, Vol. 41, No. 3 (September 2013): pg. 495-512. DOI. This article is @ Wiley and permission has been granted for this version to appear in e-Publications@Marquette. Wiley does not grant permission for this article to be further copied/distributed or hosted elsewhere without the express permission from Wiley. 
NOT THE PUBLISHED VERSION; this is the author's final, peer-reviewed manuscript. The published version may be accessed by following the link in the citation at the bottom of the page.

${ }^{14}$ These descriptions are common in Holocaust and Rwandan genocide testimony. See, for example, Langer 1991, Hatzfeld 2005. See also Hamber 2009, 75-93.

${ }^{15}$ Scheff 1994 gives an account of shame as the "master emotion" in driving violent reprisal.

${ }^{16}$ My thanks to all participants in the "Possibilities of Forgiveness" Conference organized by Jesse Couenhaven at Villanova University in February, 2012, which provided an extraordinarily nuanced examination of our differences surrounding what forgiveness is and does. Thanks also to Aline Kalbian for the invitation to present a version of the paper to the Department of Religion at Florida State University, and to the audience of faculty and graduate students for rich comments and challenges. 